\title{
Preserving Food: Freezing Fruits ${ }^{1}$
}

Judy A. Harrison and Elizabeth Andress; adapted for use in Florida by Amy Simonne ${ }^{2}$

Freezing is one of the easiest, most convenient and least time-consuming ways to prepare foods at home. Freezing does not sterilize food; the extreme cold simply retards growth of microorganisms and slows down changes that affect quality or cause spoilage in food. Properly frozen fruits will retain much of their fresh flavor and nutritive value. Their texture, however, may be somewhat softer than that of fresh fruit.

\section{Selecting Freezer Containers}

Before preparing fruit for freezing, assemble the containers you will use. The selection of containers depends on the fruit being frozen, personal preference and the types that are readily available. Containers should be moisture-vapor resistant, durable, easy to seal and should not become brittle at low temperatures.

Containers suitable for freezing fruits include plastic freezer containers, flexible freezer bags or glass canning and freezing jars. If jars are used, be sure to use wide-mouth jars for fruits packed in liquid. Regular (narrow mouth) jars break too easily at the neck.
Some household containers are not recommended for freezing. The cardboard cartons that milk, ice cream or cottage cheese come in are not moisture-vapor resistant enough. Regular (not canning) jars break too easily at freezer temperatures.

\section{Preparing the Fruit}

Sort, wash and drain fruits carefully, discarding parts that are green or of poor quality. Do not allow fruit to soak in wash water or it will lose nutrients and flavor. Prepare fruits as they will be used-stemmed, pitted, peeled or sliced. Prepare enough fruit for only a few containers at a time, especially those fruits that darken rapidly.

Do not use galvanized equipment in direct contact with fruit. The acid in the fruit dissolves zinc, which can be harmful in large amounts. Also, be wary of using iron utensils or chipped enamelware, as metallic off-flavors can result.

1. This document is Fact Sheet FCS 8767, a series of the Department of Family, Youth and Community Sciences, Florida Cooperative Extension Service, Institute of Food and Agricultural Sciences, University of Florida. Publication date: August 2004. Please visit the EDIS Web site at http://edis.ifas.ufl.edu

2. Adapted for use in Florida by Amy Simonne, assistant professor, Food Safety and Quality, Department of Family, Youth and Community Sciences, Cooperative Extension Service, Institute of Food and Agricultural Sciences, University of Florida, Gainesville, FL 32611. With permission, this publication contains the full text of Preserving Food: Freezing Fruit, edited by Judy A. Harrison, Ph.D., and Elizabeth L. Andress, Ph.D., Extension Foods Specialists, the University of Georgia and Ft. Valley State University, the U.S. Department of Agriculture and counties of the state of Georgia cooperating; and additional information from the National Center for Home Food Preservation website: http://www.uga.edu/nchfp/

The Institute of Food and Agricultural Sciences is an equal opportunity/affirmative action employer authorized to provide research, educational information and other services only to individuals and institutions that function without regard to race, color, sex, age, handicap, or national origin. For information on obtaining other extension publications, contact your county Cooperative Extension Service office. Florida Cooperative Extension Service / Institute of Food and Agricultural Sciences / University of Florida / Christine Taylor Waddill, Dean 


\section{Types of Packs}

There are several ways to pack fruits for freezing: syrup pack, sugar pack, dry pack or unsweetened pack.

Most fruits have a better texture and flavor if packed in sugar or syrup. However, the sugar is not necessary to safely preserve the fruit. For those watching their sugar intake, it can be left out or an artificial sweetener can be substituted.

The type of pack will depend on the intended use. Fruits packed in syrup are generally best for uncooked dessert use; those packed in dry sugar or unsweetened are best for most cooking purposes, because there is less liquid in the product. Whichever method you choose, be sure to leave appropriate headspace (see Table 1).

Syrup Pack - The proportion of sugar to water depends upon the sweetness of the fruit to be frozen. A 40-percent syrup is recommended for most fruits. Lighter syrups are desirable for mild-flavored fruits to prevent masking of flavors. Heavier syrups may be needed for very sour fruits. A small piece of crumpled, waterresistant paper can be used to hold the fruit down in the syrup, if necessary. See Table 2 for Syrups to Use in Freezing Fruits.

Sugar Pack - Sprinkle sugar over the fruit and mix gently until the juice is drawn out and the sugar dissolved. Soft sliced fruits such as peaches, strawberries, figs, deseeded grapes, plums and cherries will yield sufficient syrup for covering if the fruit is layered with sugar and allowed to stand for 15 minutes. Some small whole fruits may be coated with sugar and frozen.

Dry Pack - The dry pack is good for small whole fruits such as berries, that give a good quality product without sugar. Simply pack the fruit into a container, seal and freeze.

A tray pack is an alternative that may make the fruit easier to remove from the container. Simply spread a single layer of prepared fruit on shallow trays and freeze. When frozen, promptly package and return to the freezer. The fruit pieces remain loose and can be poured from the container and the package re-closed. Be sure to package the fruit as soon as it is frozen, to prevent freezer burn.

Other Unsweetened Packs - In addition to a dry pack, unsweetened fruit can be packaged in water, unsweetened juice or pectin syrup.

Unsweetened packs generally yield a product that does not have the plump texture and good color of those packed with sugar. The fruits freeze harder and take longer to thaw. However, some fruits such as raspberries, blueberries, steamed apples, gooseberries, currants, cranberries, rhubarb and figs give a good quality product without sugar.

Table 1. Headspace to Allow Between Packed Food and Closure (inches)

\begin{tabular}{|c|c|c|c|c|}
\hline \multirow[b]{2}{*}{ TYPE OF PACK } & \multicolumn{2}{|c|}{$\begin{array}{c}\text { Container with } \\
\text { wide top opening }\end{array}$} & \multicolumn{2}{|c|}{$\begin{array}{c}\text { Container with } \\
\text { narrow top opening }\end{array}$} \\
\hline & PINT & QUART & PINT & QUART \\
\hline Liquid Pack* & $1 / 2$ inch & 1 inch & $3 / 4$ inch*** & $1-1 / 2$ inch \\
\hline Dry pack** & $1 / 2$ inch & $1 / 2$ inch & 1/2 inch & $1 / 2$ inch \\
\hline
\end{tabular}




\section{Pectin Syrup}

1 box powdered pectin

2-3/4 cups water

Combine pectin and 1 cup water in saucepan. Heat to boiling and boil 1 minute. Remove from heat and add remaining water. Cool. Makes about 3 cups of moderately thick syrup. Add more water if thinner syrup is desired.

For fruit packed in water, unsweetened juice, or pectin syrup, submerge fruit by using a small piece of crumpled water resistant material, as for syrup pack. Seal tightly.

The pectin syrup is often used for fruits, such as strawberries or peaches, that retain their texture better than if frozen in water or juice.

Packs for Purées and Juices - Purées and juices can be packed as is. Sugar may be added, if desired.

\section{Using Artificial Sweeteners}

Sugar substitutes may be used in any of the unsweetened packs. Both saccharin and aspartame work well in frozen products or they can be added to the fruit just before serving.

Artificial sweeteners give a sweet flavor but do not furnish the beneficial effects of sugar, such as color protection and thickness of syrup.

Labels on the products give the equivalents to a standard amount of sugar. Use directions on the container to determine the amount of sweetener needed.

\section{Preventing Discoloration}

Some fruits such as peaches, apples, pears and apricots darken quickly when exposed to air and during freezing. They may also lose flavor when thawed. There are several ways to prevent darkening of fruit and flavor loss.
Ascorbic Acid (Vitamin C) - Ascorbic acid or vitamin $\mathrm{C}$ is effective in preventing discoloration in most fruits. Not only does it preserve natural color and flavor of fruits, but it adds nutritive value as well.

Ascorbic acid in powdered form is available at some drugstores or where freezing supplies are sold. Ascorbic acid tablets may be more readily available and less expensive, but are more difficult to dissolve. They do need to be finely crushed before use. Fillers in the tablets may make the syrup cloudy, but they are not harmful. One-half teaspoon powdered ascorbic acid $=1500 \mathrm{mg}$.

Follow the directions below for using ascorbic acid in the various types of packs. Use the amount specified in the directions for freezing each specific fruit.

- In syrup or liquid packs - Add powdered or crushed ascorbic acid to cold syrup shortly before using. Stir it in gently so you do not stir in air. Keep syrup refrigerated until use.

- In sugar or dry packs - Dissolve the ascorbic acid in two or three tablespoons of cold water and sprinkle dissolved ascorbic acid over fruit just before adding sugar.

- In crushed fruits, fruit purées and fruit juices - Add ascorbic acid to prepared fruit and stir well.

Ascorbic Acid Mixtures - Ascorbic acid mixtures are special anti-darkening preparations, usually made of ascorbic acid mixed with sugar, or with sugar and citric acid. The important active ingredient in these mixtures is ascorbic acid. Follow the manufacturer's directions for use. Do not confuse this with the ascorbic acid specified in the table, Directions for Freezing Fruits. 
Citric Acid or Lemon Juice - Citric acid or lemon juice are sometimes used in place of ascorbic acid. Neither, however, is as effective as ascorbic acid. When used in large quantities, they often mask natural fruit flavors.

Steaming - Steaming works best for fruits that will be cooked before use. Steam the fruit just until hot according to the directions for each fruit.

\section{Syrups for Freezing Fruits}

\begin{tabular}{lllll}
\hline $\begin{array}{c}\text { Types of } \\
\text { Syrup }\end{array}$ & $\begin{array}{c}\text { Percent } \\
\text { Sugar* }\end{array}$ & $\begin{array}{c}\text { Cups of } \\
\text { Sugar** }\end{array}$ & $\begin{array}{c}\text { Cups } \\
\text { of } \\
\text { Water }\end{array}$ & $\begin{array}{c}\text { Yields of } \\
\text { Syrup } \\
\text { in (Cups) }\end{array}$ \\
\hline Very Light & $10 \%$ & $1 / 2$ & 4 & $4-1 / 2$ \\
Light & $20 \%$ & 1 & 4 & $4-3 / 4$ \\
Medium & $30 \%$ & $1-3 / 4$ & 4 & 5 \\
Heavy & $40 \%$ & $2-3 / 4$ & 4 & $5-1 / 3$ \\
Very Heavy & $50 \%$ & 4 & 4 & 6 \\
\hline *Approximate. & \\
**In general, up to one-fourth of the sugar may be \\
replaced by corn syrup or mild-flavored honey. A larger \\
proportion of corn syrup may be used if a very bland, \\
light colored type is selected.
\end{tabular}

\section{Table 2.}

To make the syrup, dissolve sugar in lukewarm water, mixing until solution is clear. Chill syrup before using. Use just enough cold syrup to cover the prepared fruit after it has been placed in the container (about 1/2 to 2/3 cup of syrup per pint). To keep the fruit under the syrup, place a small piece of crumpled parchment paper or other water-resistant wrapping material on top and press fruit down into the syrup before sealing the container.

\section{Packaging, Labeling and Storing}

Most foods require headspace between the packed food and closure. This allows for expansion of the food as it freezes (see Table 1).

Before closing freezer containers, make sure sealing edges are free of moisture and food particles. Seal the container and label plainly. Include name of food, date and type of pack.

Freeze packaged fruits as quickly as possible at $0^{\circ} \mathrm{F}$ or below. For quickest freezing, place packages against the refrigerated surfaces of the freezer. Freeze no more food at one time than will freeze within 24 hours-usually two to three pounds of fruit per cubic foot of freezer space. After fruit is frozen, rearrange the packages and store close together.

Most fruits maintain high quality for eight to twelve months at $0^{\circ} \mathrm{F}$ or below; citrus fruits and citrus juices, for four to six months. Unsweetened fruits lose quality faster than those packed in sugar or syrup. Longer storage will not make the food unfit for use, but may impair its quality. It is a good idea to post a list of the frozen foods with freezing dates near the freezer and check the packages off the list as they are removed. 


\section{Directions for Freezing Fruits}

NOTE: The following fruits can all be packed using one of the unsweetened packs. However, the texture of some will be different than when sugar is used.

\begin{tabular}{|c|c|c|}
\hline Fruit & Preparation & $\begin{array}{l}\text { Type of Pack } \\
\text { (Choose One) }\end{array}$ \\
\hline Apples & $\begin{array}{l}\text { Wash, peel, core and slice crisp, } \\
\text { firm fruit. Slice medium apples into } \\
\text { twelfths, large ones into } \\
\text { sixteenths. }\end{array}$ & $\begin{array}{l}\text { - Syrup pack in a } 40 \text { percent syrup. If } \\
\text { ascorbic acid is used, use } 1 / 2 \text { teaspoon } \\
\text { per quart of syrup. } \\
\text { - Sugar pack using } 1 / 2 \text { cup sugar per } \\
\text { quart of fruit, after steaming or boiling for } \\
1-1 / 2 \text { to } 2 \text { minutes to prevent darkening. } \\
\text { Cool fruit in cold water and drain before } \\
\text { mixing fruit and sugar. } \\
\text { - Dry pack using the instructions for sugar } \\
\text { pack, but omitting the sugar. }\end{array}$ \\
\hline Apricots & $\begin{array}{l}\text { Wash, halve and pit firm, ripe } \\
\text { apricots. Peel and slice if desired. } \\
\text { If apricots are not peeled, heat in } \\
\text { boiling water for } 1 / 2 \text { minute to } \\
\text { keep skins from toughening during } \\
\text { freezing. Cool in cold water, drain. }\end{array}$ & $\begin{array}{l}\text { - Syrup pack in } 40 \text { percent syrup. If } \\
\text { ascorbic acid is used, use } 3 / 4 \text { teaspoon } \\
\text { per quart of syrup. } \\
\text { - Syrup pack using } 1 / 2 \text { cup sugar per quart } \\
\text { of fruit. Mix until all sugar is dissolved. If } \\
\text { ascorbic acid is used, use } 1 / 4 \text { teaspoon } \\
\text { dissolved in } 1 / 4 \text { cup water. }\end{array}$ \\
\hline Avocados & $\begin{array}{l}\text { Select avocados that yield to } \\
\text { gentle pressure with rinds free } \\
\text { from dark blemishes. Peel fruit, cut } \\
\text { in half and remove pit. } \\
\text { Avocados are best frozen as } \\
\text { purée - unsweetened for salads } \\
\text { and sandwiches, sweetened for } \\
\text { other uses. Avocados are not } \\
\text { satisfactorily frozen whole or } \\
\text { sliced. For a better quality product, } \\
\text { add } 1 / 4 \text { teaspoon ( } 750 \text { mg) } \\
\text { ascorbic acid to each quart of } \\
\text { purée or add } 1 \text { tablespoon lemon } \\
\text { juice for each } 2 \text { avocados. }\end{array}$ & \\
\hline Bananas & $\begin{array}{l}\text { Select firm ripe bananas. Peel; } \\
\text { mash thoroughly. Add } 1 / 2 \\
\text { teaspoon ( } 1500 \mathrm{mg}) \text { ascorbic acid } \\
\text { per cup of mashed banana. } \\
\text { Package in moisture-vapor } \\
\text { resistant container. }\end{array}$ & \\
\hline
\end{tabular}




\begin{tabular}{|c|c|c|}
\hline Fruit & Preparation & $\begin{array}{l}\text { Type of Pack } \\
\text { (Choose One) }\end{array}$ \\
\hline $\begin{array}{l}\text { Blackberries or } \\
\text { Dewberries }\end{array}$ & $\begin{array}{l}\text { Wash and sort fully ripe, firm } \\
\text { berries. Discard any soft or } \\
\text { defective berries. }\end{array}$ & $\begin{array}{l}\text { - Syrup pack in } 40 \text { to } 50 \text { percent syrup. } \\
\text { - Sugar pack using } 3 / 4 \text { cup sugar per } \\
\text { quart of berries. } \\
\text { - Use dry pack. }\end{array}$ \\
\hline $\begin{array}{l}\text { Blueberries or } \\
\text { Huckleberries }\end{array}$ & $\begin{array}{l}\text { Wash and sort fully ripe berries, } \\
\text { removing leaves, stems and } \\
\text { defective berries. }\end{array}$ & $\begin{array}{l}\text { - Use dry pack. Do not wash the berries } \\
\text { until just before serving. } \\
\text { - Crush or purée the berries and then mix } \\
\text { with } 1 \text { to } 1-1 / 8 \text { cups sugar per quart of } \\
\text { crushed or puréed berries. }\end{array}$ \\
\hline Cherries: sour & $\begin{array}{l}\text { Wash, stem and pit bright red, } \\
\text { tree-ripened cherries. }\end{array}$ & $\begin{array}{l}\text { - Syrup pack in } 60 \text { to } 65 \text { percent syrup. } \\
\text { - Sugar pack using 3/4 cups sugar per } \\
\text { quart of fruit. Mix until sugar is dissolved. }\end{array}$ \\
\hline Cherries: sweet & $\begin{array}{l}\text { Wash, stem and pit bright, fully- } \\
\text { ripe cherries of dark-colored } \\
\text { varieties. }\end{array}$ & $\begin{array}{l}\text { Syrup pack in } 40 \text { percent syrup. If } \\
\text { ascorbic acid is used, use } 1 / 2 \text { teaspoon } \\
\text { per quart of syrup. }\end{array}$ \\
\hline Citrus Fruits & $\begin{array}{l}\text { Wash and peel firm tree-ripened } \\
\text { fruit that is heavy for its size. } \\
\text { Divide fruit into sections, removing } \\
\text { membrane and seeds. }\end{array}$ & $\begin{array}{l}\text { - Syrup pack into } 40 \text { percent syrup made } \\
\text { from excess juice or water. } \\
\text { - Juice-Squeeze juice from the fruit, being } \\
\text { careful not to press any oil from the rind. } \\
\text { Freeze as is or add } 2 \text { tablespoons sugar } \\
\text { per quart of juice. }\end{array}$ \\
\hline Fresh Coconut & $\begin{array}{l}\text { Shred coconut meat or put it } \\
\text { through a food chopper. Pack into } \\
\text { containers and if desired, cover } \\
\text { with coconut liquid. }\end{array}$ & \\
\hline Cranberries & $\begin{array}{l}\text { Wash and drain firm, deep-red } \\
\text { berries with glossy skins. }\end{array}$ & $\begin{array}{l}\text { - Use dry pack } \\
\text { - Syrup pack in } 50 \text { percent syrup }\end{array}$ \\
\hline Currants & $\begin{array}{l}\text { Select plump, fully ripe bright-red } \\
\text { currants. Wash in cold water and } \\
\text { remove stems. }\end{array}$ & $\begin{array}{l}\text { - Use dry pack } \\
\text { - Syrup pack in } 50 \text { percent cold syrup } \\
\text { - Sugar pack using 3/4 cups sugar per 1- } \\
1 / 3 \text { pounds of fruit. Mix until most of } \\
\text { sugar is dissolved. }\end{array}$ \\
\hline Dates & $\begin{array}{l}\text { Select dates with good flavor and } \\
\text { tender texture. Wash and split to } \\
\text { remove pits. Leave whole or press } \\
\text { through a sieve for purée. }\end{array}$ & - Use dry pack \\
\hline
\end{tabular}




\begin{tabular}{|c|c|c|}
\hline Fruit & Preparation & $\begin{array}{l}\text { Type of Pack } \\
\text { (Choose One) }\end{array}$ \\
\hline Figs & $\begin{array}{l}\text { Wash fully ripe fruit. Peel if } \\
\text { desired. }\end{array}$ & $\begin{array}{l}\text { - Syrup pack in } 35 \text { percent syrup. If } \\
\text { ascorbic acid is used, use } 3 / 4 \text { teaspoon } \\
\text { per quart of syrup, or use } 1 / 2 \text { cup lemon } \\
\text { juice per quart of syrup. } \\
\text { - Use dry pack. If ascorbic acid is used, } \\
\text { use } 3 / 4 \text { teaspoon per } 3 \text { tablespoons of } \\
\text { water. }\end{array}$ \\
\hline Gooseberries & $\begin{array}{l}\text { Choose fully ripe berries if freezing } \\
\text { for pie; berries a little underripe for } \\
\text { jelly making. Sort, remove stems } \\
\text { and blossom ends, and wash. The } \\
\text { dry pack is best for use in pies or } \\
\text { preserves. }\end{array}$ & $\begin{array}{l}\text { - Use dry pack } \\
\text { - Syrup pack in } 50 \text { percent syrup }\end{array}$ \\
\hline Grapes & $\begin{array}{l}\text { Sort, stem and wash fully ripe, } \\
\text { firm, sweet grapes. Leave } \\
\text { seedless grapes whole; cut table } \\
\text { grapes with seeds in half and } \\
\text { remove seeds. }\end{array}$ & $\begin{array}{l}\text { - Syrup pack in } 40 \text { percent syrup } \\
\text { - Juice-Crush grapes. Add } 1 \text { cup water per } \\
\text { gallon crushed grapes. Simmer } 10 \\
\text { minutes. Strain juice through jelly bag. } \\
\text { Let juice stand overnight in refrigerator or } \\
\text { other cool place so tartrate crystals will } \\
\text { settle. Pour off clear juice and freeze. } \\
\text { (When freezing juice for jelly making, be } \\
\text { sure to use some slightly under-ripe } \\
\text { fruit.) }\end{array}$ \\
\hline Guavas & $\begin{array}{l}\text { Select ripe, tender fruit. Wash, } \\
\text { peel and cut in half. }\end{array}$ & - Syrup pack in cold 30 percent syrup. \\
\hline Loquats & $\begin{array}{l}\text { Select firm, ripe loquats. Wash, } \\
\text { remove stem, blossom end and } \\
\text { seeds. }\end{array}$ & - Syrup pack in 30 percent syrup. \\
\hline Mangos & $\begin{array}{l}\text { Select firm, ripe mangos that yield } \\
\text { to gentle pressure. Wash, peel } \\
\text { and slice. }\end{array}$ & $\begin{array}{l}\text { - Syrup pack in } 30 \text { percent syrup. } \\
\text { - Unsweetened Tray Pack - Arrange slices } \\
\text { on a flat pan and freeze. When frozen } \\
\text { remove and store in sealed containers. } \\
\text { - Purée - Press mango slices through a } \\
\text { sieve, blender chop or chop in a food } \\
\text { processor. Pack into containers with or } \\
\text { without sugar. }\end{array}$ \\
\hline $\begin{array}{l}\text { Melons: } \\
\text { Cantaloupe, } \\
\text { Honeydew or } \\
\text { Watermelon }\end{array}$ & $\begin{array}{l}\text { Select firm-fleshed, well-colored, } \\
\text { ripe melons. Remove seeds and } \\
\text { peel. Cut into slices, cubes, or } \\
\text { balls. }\end{array}$ & - Syrup pack in 30 percent syrup. \\
\hline
\end{tabular}




\begin{tabular}{|c|c|c|}
\hline Fruit & Preparation & $\begin{array}{l}\text { Type of Pack } \\
\text { (Choose One) }\end{array}$ \\
\hline $\begin{array}{l}\text { Peaches or } \\
\text { Nectarines }\end{array}$ & $\begin{array}{l}\text { Sort, wash and peel well-ripened } \\
\text { fruit. }\end{array}$ & $\begin{array}{l}\text { - Syrup pack in } 40 \text { percent syrup. If } \\
\text { ascorbic acid is used, use } 1 / 2 \text { teaspoon } \\
\text { per quart of syrup. } \\
\text { - Sugar pack using } 2 / 3 \text { cup sugar per } \\
\text { quart of fruit. Mix until sugar dissolves. } \\
\text { If ascorbic acid is used, dissolve } 1 / 4 \\
\text { teaspoon in } 1 / 4 \text { cup water and sprinkle } \\
\text { over the fruit. } \\
\text { - Crush or purée peeled and pitted } \\
\text { peaches and mix with } 1 \text { cup sugar per } \\
\text { quart prepared fruit. (Heating the pitted } \\
\text { peaches for } 4 \text { minutes in just enough } \\
\text { water to prevent scorching makes them } \\
\text { easier to purée.) If ascorbic acid is used, } \\
\text { use } 1 / 8 \text { teaspoon per quart of prepared } \\
\text { fruit. }\end{array}$ \\
\hline Pears & $\begin{array}{l}\text { Wash, peel, core and slice crisp, } \\
\text { firm, well-flavored pears. }\end{array}$ & $\begin{array}{l}\text { - Syrup Pack-Heat pears in boiling } 40 \\
\text { percent syrup for } 1 \text { to } 2 \text { minutes. Drain } \\
\text { and cool. Pack pears in cold } 40 \text { percent } \\
\text { syrup. If ascorbic acid is used, use } 3 / 4 \\
\text { teaspoon per quart of syrup. }\end{array}$ \\
\hline Persimmons & $\begin{array}{l}\text { Select orange-colored, soft-ripe } \\
\text { persimmons. Sort, wash, peel and } \\
\text { cut into sections. Press fruit } \\
\text { through a sieve to make a purée. } \\
\text { For a better product, to each quart } \\
\text { of purée add } 1 / 8 \text { teaspoon ( } 375 \\
\text { mg) ascorbic acid. Purée made } \\
\text { from native varieties needs no } \\
\text { sugar. Purée made from cultivated } \\
\text { varieties may be packed with or } \\
\text { without sugar. }\end{array}$ & $\begin{array}{l}\text { - Purée - Pack unsweetened purée into } \\
\text { containers. } \\
\text { - Or, mix } 1 \text { cup sugar with each quart ( } 2 \\
\text { pounds) of purée and pack into } \\
\text { containers. }\end{array}$ \\
\hline Pineapple & $\begin{array}{l}\text { Select firm, ripe pineapple with full } \\
\text { flavor and aroma. Pare and } \\
\text { remove core and eyes. Slice, dice, } \\
\text { crush or cut the pineapple into } \\
\text { wedges or sticks. }\end{array}$ & $\begin{array}{l}\text { - Dry Pack - Pack fruit tightly into } \\
\text { containers without sugar. }\end{array}$ \\
\hline Plums & $\begin{array}{l}\text { Sort and wash ripe fruit that is soft } \\
\text { enough to yield to gentle pressure. } \\
\text { Leave whole or cut in halves or } \\
\text { quarters and pit. }\end{array}$ & $\begin{array}{l}\text { - Syrup pack in } 40 \text { to } 50 \text { percent syrup. If } \\
\text { ascorbic acid is used, use } 1 / 2 \text { teaspoon } \\
\text { per quart of syrup. }\end{array}$ \\
\hline
\end{tabular}




\begin{tabular}{|c|c|c|}
\hline Fruit & Preparation & $\begin{array}{l}\text { Type of Pack } \\
\text { (Choose One) }\end{array}$ \\
\hline Pomegranates & $\begin{array}{l}\text { Select fully ripe pomegranates. } \\
\text { Wash and cut in half. Place cut } \\
\text { side down and rap the shell with a } \\
\text { blunt instrument such as a } \\
\text { hammer handle. This will break } \\
\text { section walls and open juice sacs. }\end{array}$ & - Syrup pack in cold 30 percent syrup. \\
\hline Raspberries & $\begin{array}{l}\text { Wash and drain, fully-ripe, well- } \\
\text { colored berries }\end{array}$ & $\begin{array}{l}\text { - Sugar pack using 3/4 cup sugar for each } \\
\text { quart of berries. Mix carefully to avoid } \\
\text { crushing. } \\
\text { - Syrup pack in } 40 \text { percent sugar. } \\
\text { - Use dry pack. }\end{array}$ \\
\hline Rhubarb & $\begin{array}{l}\text { Choose firm, tender, well-colored } \\
\text { stalks with good flavor and few } \\
\text { fibers. Wash, trim and cut into } \\
\text { lengths to fit the package. Heating } \\
\text { rhubarb in boiling water for } 1 \\
\text { minute and cooling promptly in } \\
\text { cold water helps retain color and } \\
\text { flavor. }\end{array}$ & $\begin{array}{l}\text { - Dry Pack - Pack either raw or preheated } \\
\text { rhubarb tightly into containers without } \\
\text { sugar. } \\
\text { - Syrup Pack - Pack either raw or } \\
\text { preheated rhubarb tightly into containers, } \\
\text { cover with cold } 40 \text { percent syrup. }\end{array}$ \\
\hline Strawberries & $\begin{array}{l}\text { Wash and remove caps from fully } \\
\text { ripe, firm berries with a deep-red } \\
\text { color. }\end{array}$ & $\begin{array}{l}\text { - Syrup pack whole berries using a } 50 \\
\text { percent syrup. } \\
\text { - Sugar pack whole, sliced or crushed } \\
\text { berries using } 3 / 4 \text { cup sugar per quart of } \\
\text { fruit. }\end{array}$ \\
\hline
\end{tabular}

